\title{
Effects of tris(1,3-dichloro-2-propyl) phosphate and triphenyl phosphate on receptor-associated mRNA expression in zebrafish embryos/larvae
}

\author{
Chunsheng Liu ${ }^{\mathrm{a}, *}$, Qiangwei Wang ${ }^{\mathrm{b}}$, Kang Liang ${ }^{\mathrm{c}}$, Jingfu Liu ${ }^{\mathrm{c}}$, Bingsheng Zhou ${ }^{\mathrm{b}}$, Xiaowei Zhang ${ }^{\mathrm{a}}$, \\ Hongling Liu ${ }^{\mathrm{a}}$, John P. Giesy ${ }^{\mathrm{d}, \mathrm{e}, \mathrm{f}, \mathrm{g}}$, Hongxia $\mathrm{Yu}^{\mathrm{a}, *}$ \\ a State Key Laboratory of Pollution Control and Resource Reuse E School of the Environment, Nanjing University, Nanjing, China \\ b State Key Laboratory of Freshwater Ecology and Biotechnology, Institute of Hydrobiology, Chinese Academy of Sciences, Wuhan 430072, China \\ c State Key Laboratory of Environmental Chemistry and Ecotoxicology, Research Center for Eco-Environmental Sciences, Chinese Academy of Sciences, P.O. Box 2871, \\ Beijing 100085, China \\ d Toxicology Centre, University of Saskatchewan, Saskatoon, Saskatchewan, Canada S7N 5B3 \\ e Department of Veterinary Biomedical Sciences, University of Saskatchewan, Saskatoon, Saskatchewan, Canada S7N 5B3 \\ f Zoology Department, Center for Integrative Toxicology, Michigan State University, East Lansing, MI 48824, USA \\ ${ }^{g}$ Department of Biology and Chemistry, City University of Hong Kong, Kowloon, Hong Kong, China
}

\section{A R T I C L E I N F O}

\section{Article history:}

Received 17 October 2012

Received in revised form

22 November 2012

Accepted 11 December 2012

\section{Keywords:}

TDCPP

TPP

mRNA expression

Receptor

Genomics

\begin{abstract}
A B S T R A C T
Tris(1,3-dichloro-2-propyl) phosphate (TDCPP) and triphenyl phosphate (TPP) are frequently detected in biota, including fish. However, knowledge of the toxicological and molecular effects of these currently used flame retardants is limited. In the present study, an in vivo screening approach was developed to evaluate effects of TDCPP and TPP on developmental endpoints and receptor-associated expression of mRNA in zebrafish embryos/larvae. Exposure to TDCPP or TPP resulted in significantly smaller rates of hatching and survival, in dose- and time-dependent manners. The median lethal concentration $\left(\mathrm{LC}_{50}\right)$ was $7.0 \mathrm{mg} / \mathrm{L}$ for TDCPP and $29.6 \mathrm{mg} / \mathrm{L}$ for TPP at 120 hour post-fertilization (hpf). Real-time PCR revealed alterations in expression of mRNAs involved in aryl hydrocarbon receptors (AhRs)-, peroxisome proliferator-activated receptor alpha (PPAR $\alpha$ )-, estrogenic receptors (ERs)-, thyroid hormone receptor alpha (TR $\alpha$ )-, glucocorticoid receptor (GR)-, and mineralocorticoid receptor (MR)-centered gene networks. Exposure to positive control chemicals significantly altered abundances of mRNA in corresponding receptor-centered gene networks, a result that suggests that it is feasible to use zebrafish embryos/larvae to evaluate effects of chemicals on mRNA expression in these gene networks. Exposure to TDCPP altered transcriptional profiles in all six receptor-centered gene networks, thus exerting multiple toxic effects. TPP was easily metabolized and its potency to change expression of mRNA involved in receptor-centered gene networks was weaker than that of TDCPP. The PPAR $\alpha$ - and TR $\alpha$-centered gene networks might be the primary pathways affected by TPP. Taken together, these results demonstrated that TDCPP and TPP could alter mRNA expression of genes involved in the six receptor-centered gene networks in zebrafish embryos/larvae, and TDCPP seemed to have higher potency in changing the mRNA expression of these genes.
\end{abstract}

(C) 2012 Elsevier B.V. All rights reserved.

\section{Introduction}

Organophosphate esters (OP esters) are a group of synthetic chemicals that were widely used as flame retardants and plasticizers in various products, such as plastics, foams, textiles, varnishes, electronics equipment and furniture with high-production volume worldwide (van der Veen and de Boer, 2012). Recently, the use of OP esters has been increasing gradually as other flame retardants such as penta- and octabrominated diphenyl ethers (PBDEs) have

\footnotetext{
* Corresponding authors at: School of the Environment, Nanjing University, Nanjing 210093, China. Tel.: +86 13062571352.

E-mail addresses: liuchunshengidid@126.com (C. Liu),yuhx@nju.edu.cn (H.Yu).
}

been phased out of use (Reemtsma et al., 2008; van der Veen and de Boer, 2012).

Among OP esters, tris(1,3-dichloro-2-propyl) phosphate (TDCPP) and triphenyl phosphate (TPP) are commonly used with annual production in the United States been estimated to be between $4.5 \times 10^{5}$ and $4.5 \times 10^{6} \mathrm{~kg}$ from 1986 to 1990 , and increased to between $4.5 \times 10^{6}$ and $2.3 \times 10^{7} \mathrm{~kg}$ in 1994,1998 , 2002 and 2006 (U.S. Environmental Protection Agency Inventory Update Reporting, http://www.epa.gov/iur). Environmental monitoring has demonstrated that TDCPP and TPP were distributed in indoor air, surface water, drinking water, sediment, wildlife and human tissues (Andresen et al., 2004; Bacaloni et al., 2007; Cao et al., 2012; Chen et al., 2011; Hartmann et al., 2004; Marklund et al., 2005; Stackelberg et al., 2004; Sundkvist et al., 2010; van 
der Veen and de Boer, 2012). For example, in Germany, TDCPP has been detected in surface water at a maximum concentration of $50 \mathrm{ng} / \mathrm{L}$ in the River Ruhr (Andresen et al., 2004). Concentrations of 11 OP esters were measured in fishes and mussels from Swedish lakes and coastal areas, and TPP was one of the most frequently detected compounds, with concentrations ranging from 21 to $180 \mathrm{ng} / \mathrm{g}$ lipid weight (Sundkvist et al., 2010).

Limited information is currently available on the thresholds and mechanisms of toxicity of TDCPP and TPP. Results of epidemiology and controlled laboratory studies with animals suggest that TDCPP or/and TPP cause developmental toxicity and endocrinedisruption (Dishaw et al., 2011; C. Liu et al., 2012; X. Liu et al., 2012; McGee et al., 2012; Meeker and Stapleton, 2010). For example, McGee et al. (2012) reported that exposure to TDCPP $(0.05-50 \mu \mathrm{M})$ from 5.25 hpf to $96 \mathrm{hpf}$ in zebrafish embryos/larvae caused developmental toxicity by altering embryogenesis, with a $\mathrm{LC}_{50}$ of $8.5 \mu \mathrm{M}$ (3.7 mg/L). C. Liu et al. (2012) and X. Liu et al. (2012) reported that exposure to TDCPP or TPP significantly up-regulated expression of mRNA of genes involved in steroidogenesis and resulted in greater concentrations of both testosterone $(T)$ and $17 \beta$-estradiol (E2) in culture medium of H295R cells and in blood plasma of zebrafish. Using primary cultured avian hepatocytes, Crump et al. (2012) demonstrated that TDCPP could alter abundances of mRNA of genes associated with phase I and II metabolism, lipid regulation, and growth.

Coordinated expression of gene networks in various metabolic, physiological, and developmental processes were, in large part, mediated by a superfamily of receptors, mostly nuclear receptors (McKenna and O'Malley, 2002). Results of multiple studies have demonstrated that several environmental pollutants, such as dioxin-like chemicals and estrogens, can bind to one or several receptors and alter related expression of mRNA that can cause adverse effects on health (Ankley et al., 2010; Mandal, 2005; Mortensen and Arukwe, 2007). In the present study, 48 genes involved in six receptor-centered gene networks were collected from SABioscience Gene Network Central (http://www. sabiosciences.com/genenetwork/genenetworkcentral.php) and previous published data in fishes (Pellegrini et al., 2005; Zhang et al., 2008), and were integrated as "associations" and visualized as networks as described in SABioscience Gene Network Central. Furthermore, quantitative real-time polymerase chain reaction (qRT-PCR) was developed to evaluate effects of six positive control chemicals and two OP esters (TDCPP and TPP) on expression of mRNA of receptors and selected associated genes in zebrafish embryos/larvae.

\section{Materials and methods}

\subsection{Materials and reagents}

Perfluorooctanesulfonic acid potassium salt (PFOS) was obtained from Tokyo Kasei Kogyo Co. Ltd. (Tokyo, Japan). Benzo[a]pyrene (B[a]P), 17 $\beta$-estradiol (E2), 3,3',5-triiodo-Lthyronine (T3), dexamethasone (DEX), fludrocortisone acetate (FCA), tris(1,3-dichloro-2-propyl) phosphate (TDCPP), triphenyl phosphate (TPP) and 3-amino-benzoic acid ethyl ester, methanesulfonate salt (MS-222) were purchased from Sigma (St. Louis, MO, USA). All chemicals were dissolved in dimethyl sulfoxide (DMSO) as stock solutions and stored in $-20^{\circ} \mathrm{C}$. RNAlater RNA Stabilization Reagents were obtained from QIAGEN (Tokyo, Japan). GeneJET ${ }^{\mathrm{TM}}$ RNA Purification and Maxima ${ }^{\circledR}$ First Strand cDNA Synthesis Kits were purchased from Fermentas (St Leon-Rot, Germany). SYBR ${ }^{\circledR}$ Realtime PCR Master Mix -Plus- Kits were purchased from Toyobo (Tokyo, Japan). Standards of TDCPP and TPP were purchased from Dr. Ehrenstorfer GmbH (Germany). Tributyl- $D_{27}$-phosphate $\left(\right.$ TnBP- $\left.\mathrm{D}_{27}\right)$ was obtained from Cambridge Isotope Laboratories (UK).

\subsection{Animals and chemical exposure protocol}

Fertilization of eggs and culture of adult zebrafish (AB strain, 6-month old) were performed as previously described (Liu et al., 2009; Shi et al., 2009). Eggs were examined under a stereo microscope and those exhibiting normal development were used for subsequent experiments. Briefly, eggs were randomly distributed into six-well culture plates. Each well contained 20 eggs, with $10 \mathrm{~mL}$ of exposure solution. Eggs were exposed from 4 to 120 hour post-fertilization (hpf), by which time they had developed into freeswimming larvae and most organs had completed development (Amsterdam et al., 2004). Each exposure concentration was replicated in four separate wells. Control groups received 0.01\% DMSO $(\mathrm{v} / \mathrm{v})$. At $48 \mathrm{hpf}$ exposure solutions were replaced by fresh water or exposed to appropriate concentration and exposure continued until $120 \mathrm{hpf}$. For positive control chemicals, exposure concentrations were $10 \mu \mathrm{g} \mathrm{B}[\mathrm{a}] \mathrm{P} / \mathrm{L}, 5 \mathrm{mg}$ PFOS/L, $200 \mu \mathrm{g}$ E2/L, $30 \mu \mathrm{g}$ T3/L, $25 \mathrm{mg}$ DEX/L, and $25 \mathrm{mg}$ FCA/L. These concentrations were selected based on published data or range-finding studies to determine concentrations that significantly altered expression of corresponding receptor-associated mRNAs (Duarte-Guterman et al., 2010; Kazeto et al., 2004; Krøvel et al., 2008; J. Wang et al., 2011; X. Wang et al., 2011; Tseng et al., 2005). For TDCPP and TPP, exposure experiments included two parts. First, zebrafish embryos were exposed to $0,0.8$, $4,20,100$ or $500 \mathrm{mg} / \mathrm{L} \mathrm{TDCPP}$ or TPP from 4 to $120 \mathrm{hpf}$, and rates of hatching and survival monitored. Second, based on the results of the acute toxicity test, a different set of zebrafish embryos was exposed to $0.02,0.2$ or $2 \mathrm{mg} / \mathrm{L}$ TDCPP or TPP from 4 to $120 \mathrm{hpf}$, and effects on expression of mRNA of genes in six receptor-centered networks were determined. After exposure, larvae were anesthetized with MS-222, and preserved in RNAlater RNA Stabilization Reagents for subsequent total RNA isolation.

\subsection{Quantification of TDCPP or TPP in exposure solutions}

In acute toxicity test, exposure solutions were collected at 4, 48(1) (prior to renewing of exposure solutions), 48(2) (after renewing of exposure solutions) and $120 \mathrm{hpf}$ in $0.8-\mathrm{mg} / \mathrm{L}$ treatment group for TDCPP or TPP measurement. Concentrations of TDCPP or TPP in exposure solutions were also determined at 48(2) (after renewing of exposure solutions) and $120 \mathrm{hpf}$ when zebrafish embryos were exposed to $0.02,0.2$ and $2 \mathrm{mg} / \mathrm{L}$ TDCPP or TPP. Quantification of TDCPP or TPP was performed using a published protocol (J. Wang et al., 2011; X. Wang et al., 2011). Briefly, exposure solutions were filtered through $0.22 \mu \mathrm{m}$ nylon membrane filters (Jiuding HighTech Filtration, China), and the filtered samples were immediately used for LC-MS/MS analysis. The calibration and quantification were performed by using an internal standard method with TDCPP or TPP standard prepared in water/acetonitrile (60/40), with TnBP$\mathrm{D}_{27}$ internal standard.

\subsection{Quantitative real-time polymerase chain reaction ( $q R T-P C R$ )}

Total RNA was isolated from larvae using GeneJET ${ }^{\mathrm{TM}}$ RNA Purification kits following the manufacturer's instructions. Concentration of total mRNA was determined and quality was verified by use of a previously reported protocol (C. Liu et al., 2012; X. Liu et al., 2012). Syntheses of first-strand cDNA and qRT-PCR were performed by use of Maxima ${ }^{\circledR}$ First Strand cDNA Synthesis and SYBR ${ }^{\circledR}$ Realtime PCR Master Mix -Plus- Kits according to the manufacturer's instructions (C. Liu et al., 2012; X. Liu et al., 2012). Sequences for primers were designed using Primer 3 software (http://frodo.wi.mit.edu/as) (Table S1). Housekeeping 
genes glyceraldehyde-3-phosphate dehydrogenase (GAPDH) and 18S small subunit ribosomal RNA (18S rRNA) did not vary upon chemical exposure and were used as internal controls. The thermal cycle was set at $95^{\circ} \mathrm{C}$ for $2 \mathrm{~min}$, followed by 40 cycles of $95^{\circ} \mathrm{C}$ for $15 \mathrm{~s}$ and $60^{\circ} \mathrm{C}$ for $1 \mathrm{~min}$. The mRNA expression level of gene was normalized to housekeeping mRNA contents using the $2^{-\Delta \Delta \mathrm{Ct}}$ method. The average cycle threshold $(C t)$ value of GAPDH and $18 \mathrm{~S}$ rRNA was used for the expression calculation of target genes. Each concentration included four biological replicates and each replicate included 15 larvae.

\subsection{Statistical analyses}

Normality and homogeneity of data were evaluated by use of the Kolmogorov-Smirnow and Levene's tests, respectively. Oneway analysis of variance (ANOVA) and Tukey's multiple range test were used to determine the significant differences between the control and each exposure group. A level of significance for type I error $(\alpha)$ was set at $P$-value $<0.05$. All data were expressed as mean \pm SEM. The statistical analyses were conducted using Kyplot Demo 3.0 software (Tokyo, Japan)

\section{Results}

\subsection{Quantification of TDCPP or TPP in exposure solutions}

In time-course study, mean concentrations of TDCPP in $0.8-\mathrm{mg} / \mathrm{L}$ treatment group were $0.80,0.74,0.84$ and $0.80 \mathrm{mg} / \mathrm{L}$ at $4,48(1)$ (prior to renewing of exposure solutions), 48(2) (after renewing of exposure solutions), and $120 \mathrm{hpf}$, respectively. Mean concentrations of TPP in $0.8-\mathrm{mg} / \mathrm{L}$ treatment group were $0.83,0.79,0.80$ and $0.00 \mathrm{mg} / \mathrm{L}$ at $4,48(1)$ (prior to renewing of exposure solutions), 48 (2) (after renewing of exposure solutions), and $120 \mathrm{hpf}$, respectively. No TDCPP or TPP were detected in control groups.

Based on results above, we measured concentrations of TDCPP or TPP in $0.02,0.2$ and $2 \mathrm{mg} / \mathrm{L}$ treatment groups at 48 (2) (after renewing of exposure solutions) and $120 \mathrm{hpf}$. Mean concentrations of TDCPP in 0.02, 0.2 and $2 \mathrm{mg} / \mathrm{L}$ treatment groups were $0.02,0.19$ and $1.96 \mathrm{mg} / \mathrm{L}$ at $48(2) \mathrm{hpf}$ and $0.02,0.17$ and $1.89 \mathrm{mg} / \mathrm{L}$ at $120 \mathrm{hpf}$, respectively. Mean concentrations of TPP in $0.02,0.2$ and $2 \mathrm{mg} / \mathrm{L}$ treatment groups were $0.02,0.19$ and $1.80 \mathrm{mg} / \mathrm{L}$ at $48(2) \mathrm{hpf}$ and $0.00,0.00$ and $1.39 \mathrm{mg} / \mathrm{L}$ at $120 \mathrm{hpf}$, respectively.

\subsection{Acute toxicity}

No significant effects on rates of hatching of eggs or survival and malformation (spinal curvature, pericardial edema and yolk sac edema) of larvae were observed after exposure to $10 \mu \mathrm{g} \mathrm{B}[\mathrm{a}] \mathrm{P} / \mathrm{L}$, $5 \mathrm{mg}$ PFOS/L, $200 \mu \mathrm{g} \mathrm{E2/L,} 30 \mu \mathrm{g}$ T3/L, $25 \mathrm{mg} \mathrm{DEX/L,} \mathrm{or} 25 \mathrm{mg}$ FCA/L. Rates of hatching and survival were $>90 \%$ and rate of malformation was $<5 \%$ in all exposure groups including controls.

Exposure to TDCPP caused dose- and time-dependent decrease in the rate of hatching and survival (Fig. 1). No significant effects on survival were observed in embryos/larvae exposed to 0.8 or $4 \mathrm{mg} / \mathrm{L} 12,24,48,72,96$ and $120 \mathrm{hpf}$. However, exposure to $20 \mathrm{mg} / \mathrm{L}$ TDCPP resulted in significantly lesser survival by $18.2 \%, 20.1 \%$, $20.1 \%, 100 \%$ and $100 \%$ at $24,48,72,96$ and $120 \mathrm{hpf}$, respectively, relative to the control. Exposure to greater concentrations (100 or $500 \mathrm{mg} / \mathrm{L}$ ) caused $100 \%$ mortality by $12 \mathrm{hpf}$. The 120 -hpf median lethal concentration $\left(\mathrm{LC}_{50}\right)$ was $7.0 \mathrm{mg}$ TDCPP/L. Treatment with 0.8 or $4 \mathrm{mg} / \mathrm{L}$ TDCPP did not significantly alter rates of hatching at $48,54,60$ or 72 hpf. However, significantly lower rates of hatching were observed at 54, 60 and $72 \mathrm{hpf}$ when exposed to 20, 100 or $500 \mathrm{mg} / \mathrm{L}$. No significant effects on hatching, survival or malformation (spinal curvature, pericardial edema and yolk sac edema) were observed when exposed to $0.02,0.2$ or $2 \mathrm{mg} / \mathrm{L}$ TDCPP. Rates
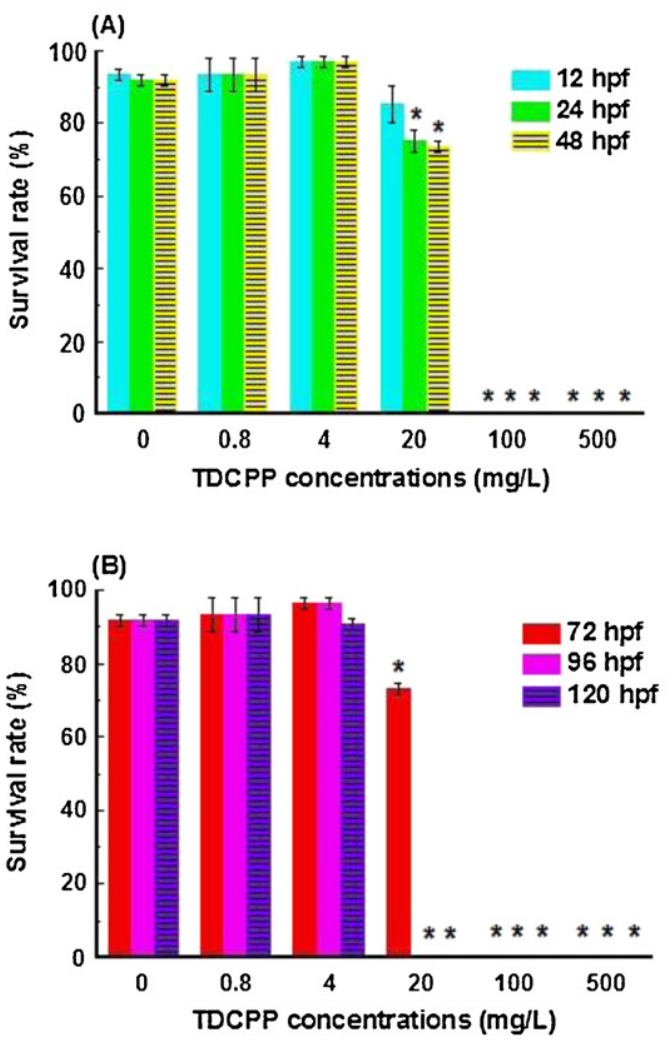

(C)

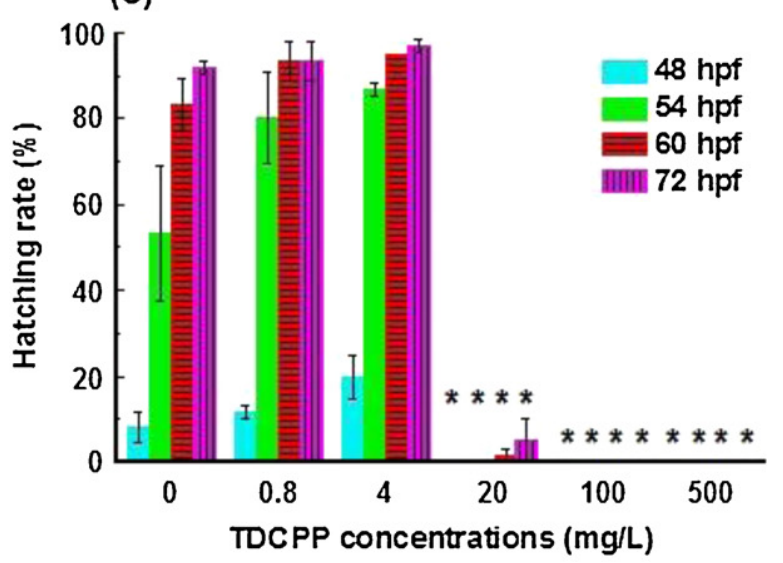

Fig. 1. Cumulative survival ( $A$ and $B$ ) and hatching $(C)$ of zebrafish embryos/larvae exposed to $0,0.8,4,20,100$ or $500 \mathrm{mg} / \mathrm{L}$ tris(1,3-dichloro-2-propyl) phosphate (TDCPP). Values represent mean $\pm \operatorname{SEM}(n=4$ samples). .Significant difference from the control group is indicated by ${ }^{*} P<0.05$.

of hatching and survival were $>90 \%$ and rate of malformation was $<5 \%$ in all exposure groups including controls.

TPP caused dose- and time-dependent decrease in the rate of hatching and survival (Fig. 2). At 12, 24 and 48 hpf exposure to 0.8 , $4,20,100$ or $500 \mathrm{mg}$ TPP/L caused no significant effects on rates of hatching and survival. However, at 72, 96 and $120 \mathrm{hpf}$, exposure to 100 or $500 \mathrm{mg}$ TPP/L resulted in $100 \%$ mortality. The $\mathrm{LC}_{50}$ was $29.6 \mathrm{mg}$ TPP/L at $120 \mathrm{hpf}$. Rates of hatching at $48 \mathrm{hpf}$ were not significantly different from that of the control, when exposed to $0.8,4$, 20,100 or $500 \mathrm{mg}$ TPP/L. However, treatment with 100 or $500 \mathrm{mg}$ TPP/L resulted in significantly lesser rates of hatching that was $100 \%$ at 54 hpf. No significant effects on rates of survival, hatching or malformation (spinal curvature, pericardial edema and yolk sac edema) were observed when exposed to $0.02,0.2$ or $2 \mathrm{mg} \mathrm{TPP} / \mathrm{L}$. Rates of 

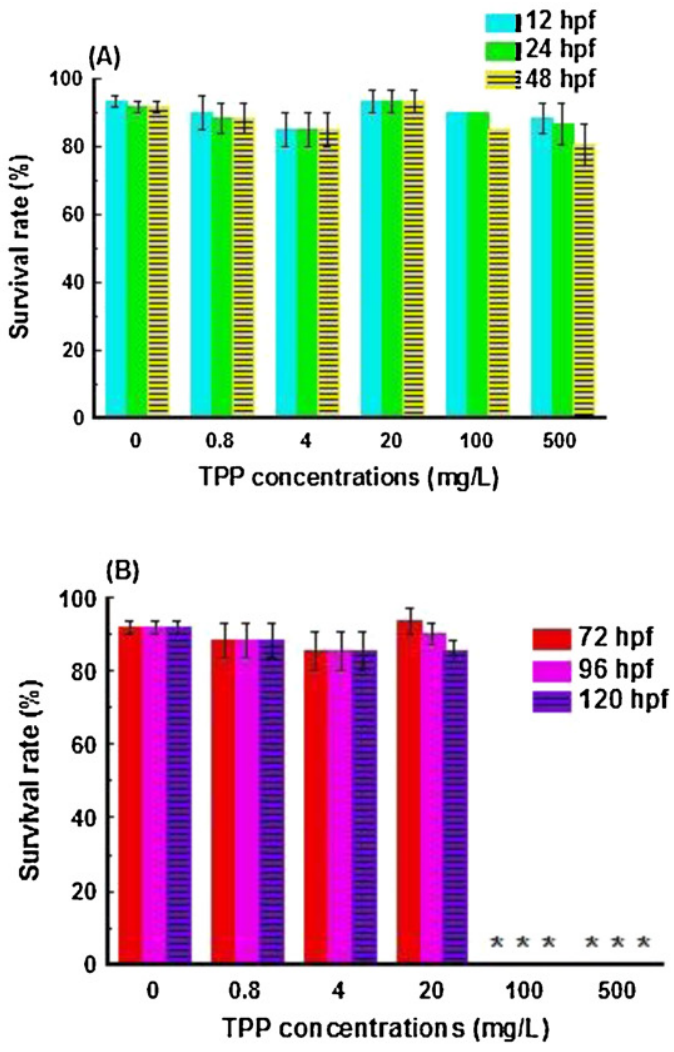

(C)

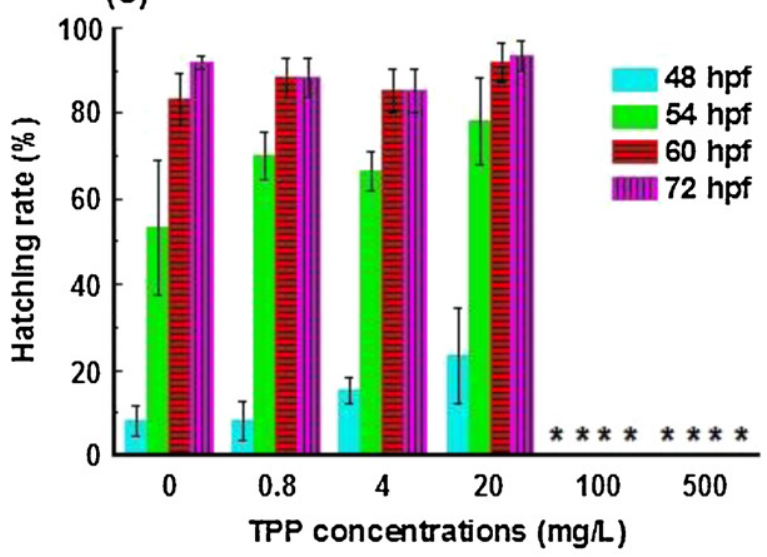

Fig. 2. Cumulative survival (A and $B$ ) and hatching (C) of zebrafish embryos/larvae exposed to $0,0.8,4,20,100$ or $500 \mathrm{mg} / \mathrm{L}$ tris(1,3-dichloro-2-propyl) phosphate (TPP). Values represent mean $\pm \operatorname{SEM}(n=4$ samples). Significant difference from the control group is indicated by ${ }^{*} P<0.05$.

hatching and survival were $>90 \%$ and rate of malformation was $<5 \%$ in all exposure groups including controls.

\subsection{Transcriptional responses to positive control chemicals}

Exposure to positive cont1rol chemicals significantly altered expression of mRNA of genes in the six receptor-centered networks (Table S2 and Fig. 3). Exposure to $10 \mu \mathrm{g}$ B[a]P/L significantly up-regulated mRNA expression of aryl hydrocarbon receptor $1 \mathrm{~b}$ (AhR1b), aryl hydrocarbon receptor 2 (AhR2), AhR repressor a (AhRRa), aryl hydrocarbon receptor interacting protein (AIP), cytochrome P450 1A1 (CYP1A1), nuclear receptor co-repressor 2 (NCOR2), cytochrome P450 1B1 (CYP1B1) and sp1 transcriptional factor (SP1) genes by 2.3-, 2.2-, 1.4-, 1.2-, 2.5-, 1.3-, 1.6- and 1.3-fold, respectively. Exposure to $5 \mathrm{mg}$ PFOS/L significantly up-regulated the expression of mRNA of peroxisome proliferator-activated receptor alpha (PPAR $\alpha$ ) (1.7-fold), lipoprotein lipase (LPL) (2.0fold), interleukin 8 (IL8) (1.4-fold) and interleukin 6 (IL6) (5.3-fold) genes, while mRNA expression of dUTP pyrophosphatase (DUT) gene was significantly down-regulated by 0.6 -fold. Expression of mRNA of other genes, such as peroxisome proliferator-activated receptor gamma coactivator 1 alpha (PPARgc1a) and peroxisome proliferator-activated receptor gamma (PPARg) gene were not altered by exposure to PFOS. Significant up-regulation of expression of mRNA of estrogen receptor 1 (ER1) (2.1-fold), estrogen receptor $2 b$ (ER2b) (1.7-fold), vitellogenin 1 (VTG1) (9.8-fold), vitellogenin 2 (VTG2) (6.1-fold), vitellogenin 4 (VTG4) (40.8-fold), vitellogenin 5 (VTG5) (9.0-fold), and progesterone receptor (PGR) (2.1-fold) genes were observed upon exposure to $200 \mu \mathrm{g}$ E2/L, while expressions of mRNA of estrogen receptor 2a (ER2a) and cyclin D1 (CCND1) genes were significantly down-regulated by 0.6- and 0.7-fold, respectively. Treatment with thyroid hormone at a concentration of $30 \mu \mathrm{g}$ T3/L significantly up-regulated expression of mRNA of thyroid hormone receptor alpha (TR $\alpha)$ (4.9-fold), PPARgc1a (1.3-fold), NCOR (1.3-fold), C1D nuclear receptor corepressor (C1D) (1.3-fold), NCOR2 (1.4-fold) and histone deacetylase 3 (HDAC3) (1.3-fold) genes, while mRNA expression of fusion (FUS) gene was not significantly altered. Exposure to $25 \mathrm{mg} / \mathrm{L}$ of the glucocorticoid receptor (GR) agonist DEX caused significant upregulation of mRNA expression of GR (2.1-fold), heparanase (HPSE) (1.9-fold), P65 transcriptional factor (RelA) (1.6-fold), and heat shock protein alpha, class 1 member 1 (HSP90aa 1 ) (1.2-fold) genes, while mRNA expression of death-associated protein 3 (DAP3) and transforming growth factor beta 1 (TGFb1) genes was not significantly changed. Exposure to $25 \mathrm{mg} / \mathrm{L}$ of the mineralocorticoid receptor (MR) agonist FCA significantly up-regulated expression of mRNA of MR (2.7-fold), HPSE (2.2-fold), adrenergic receptor beta 2a (ADRB2a) (1.7-fold) and epidermal growth factor receptor (EGFR) (1.6-fold) genes, while expression of mRNA of 11 beta hydroxysteroid dehydrogenase (11ßHSD), adrenergic receptor beta $2 \mathrm{~b}$ (ADRB2b) and ubiquitin-conjugating enzyme 2I(UBE2I) genes were not changed.

\subsection{Transcriptional responses to TDCPP}

Exposure to TDCPP caused dose-dependent alterations in expression of mRNA related to the following receptor-centered gene networks: AhRs, PPAR $\alpha, \mathrm{ERs}, \mathrm{TR} \alpha, \mathrm{GR}$ and MR (Table S2 and Fig. 4). Exposure to the two concentrations of TDCPP caused significant up-regulation in expression of mRNA of AhR1b (1.2- and 1.2-fold), AIP (1.2- and 1.5-fold), aryl hydrocarbon receptor nuclear translocator 2 (ARNT2) (1.2- and 1.7-fold), aryl hydrocarbon receptor nuclear translocator-like 1a (ARNTl1a) (1.5- and 2.0-fold), aryl hydrocarbon receptor nuclear translocator-like $1 \mathrm{~b}$ (ARNTl1b) (1.5and 2.1-fold), NCOR2 (1.3- and 1.5-fold), CYP1B1 (1.3- and 1.4-fold) and SP1 (1.3- and 1.4-fold) genes in 0.2 and $2 \mathrm{mg} / \mathrm{L}$ exposure groups. TDCPP significantly up-regulated mRNA expression of all of the genes selected for the PPAR $\alpha$-centered gene network, in a dosedependent manner. PPARgc1a and LPL mRNA expressions were significantly up-regulated by 1.4 - and 2.1-fold, and 1.3- and 2.0fold when exposed to 0.2 or $2 \mathrm{mg}$ TDCPP/L, respectively. Exposure to $0.02 \mathrm{mg}$ TDCPP/L significantly up-regulated expression of mRNAs of ER1 (1.8-fold), ER2b (1.5-fold), VTG1 (1.8-fold), VTG2 (1.9-fold), VTG4 (2.0-fold), VTG5 (2.2-fold) and PGR (1.8-fold) genes. No significant effects were observed at the two greatest concentrations ( 0.2 and $2 \mathrm{mg} / \mathrm{L}$ ). TDCPP caused significant up-regulation of expression of mRNA of ER2a, NCOA1, NCOA2, NCOA3, and CCND1 genes relative to the control in larvae exposed to 0.2 or $2 \mathrm{mg} / \mathrm{L}$. TDCPP significantly up-regulated expression of mRNA of genes in the 

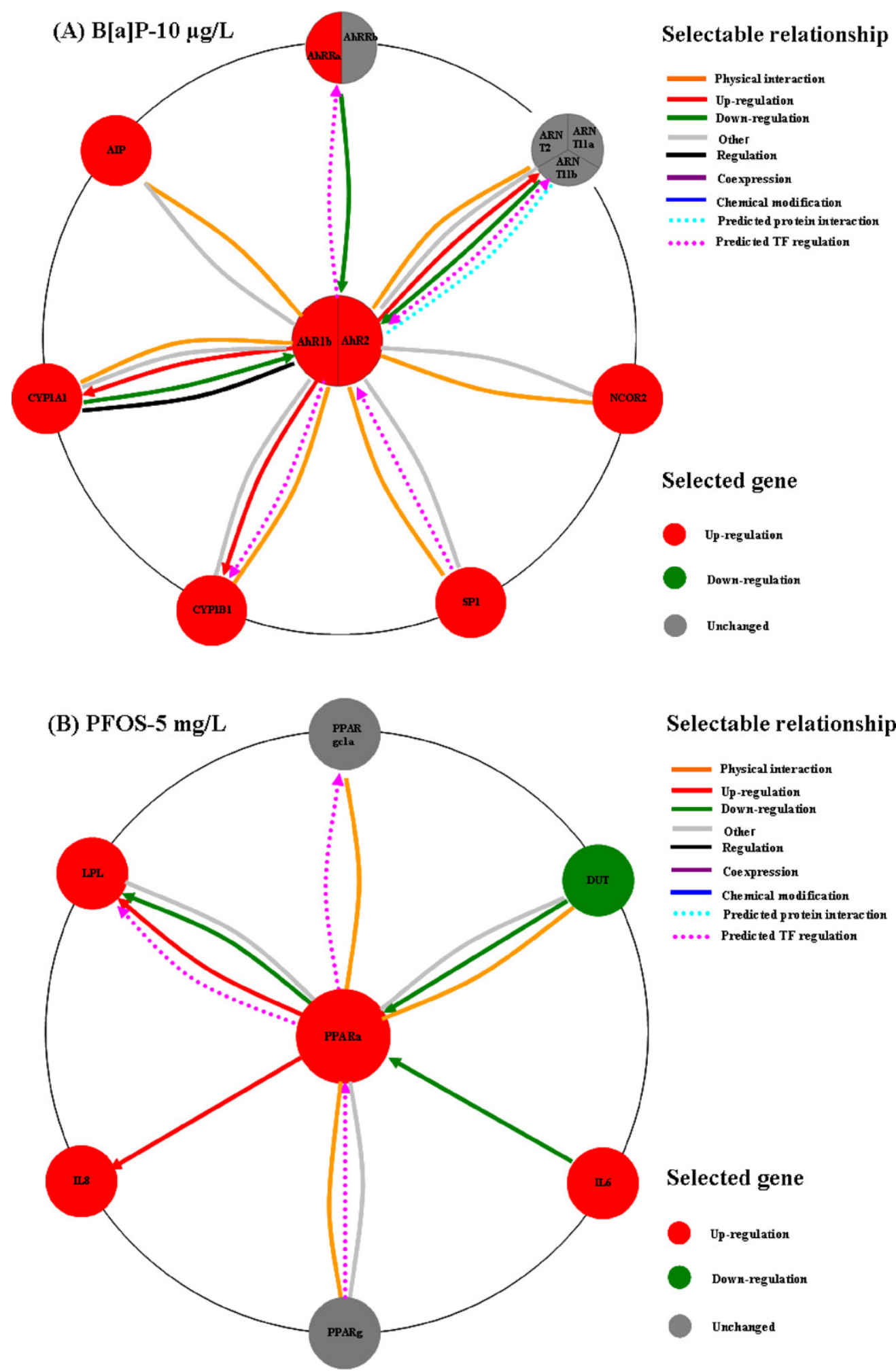

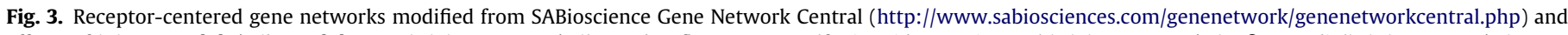

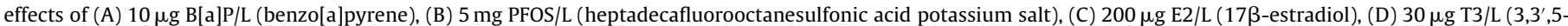

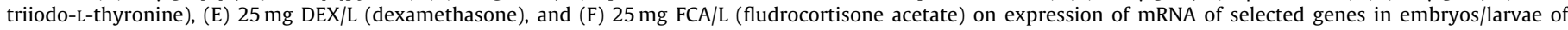

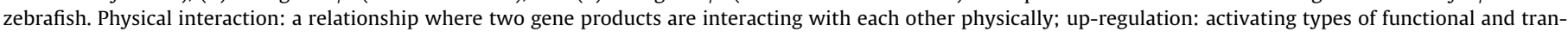

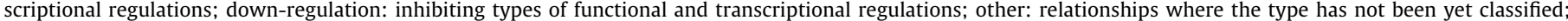

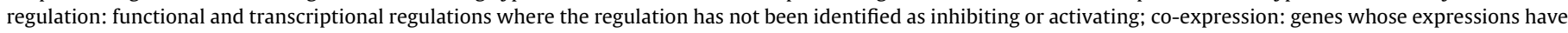

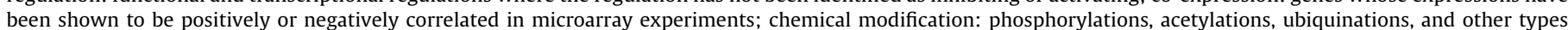

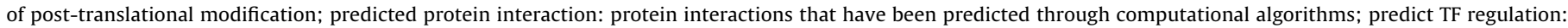
transcriptional regulations where cis-regulatory element for a given transcription factor (TF) have been found in the promoter of a target gene. 


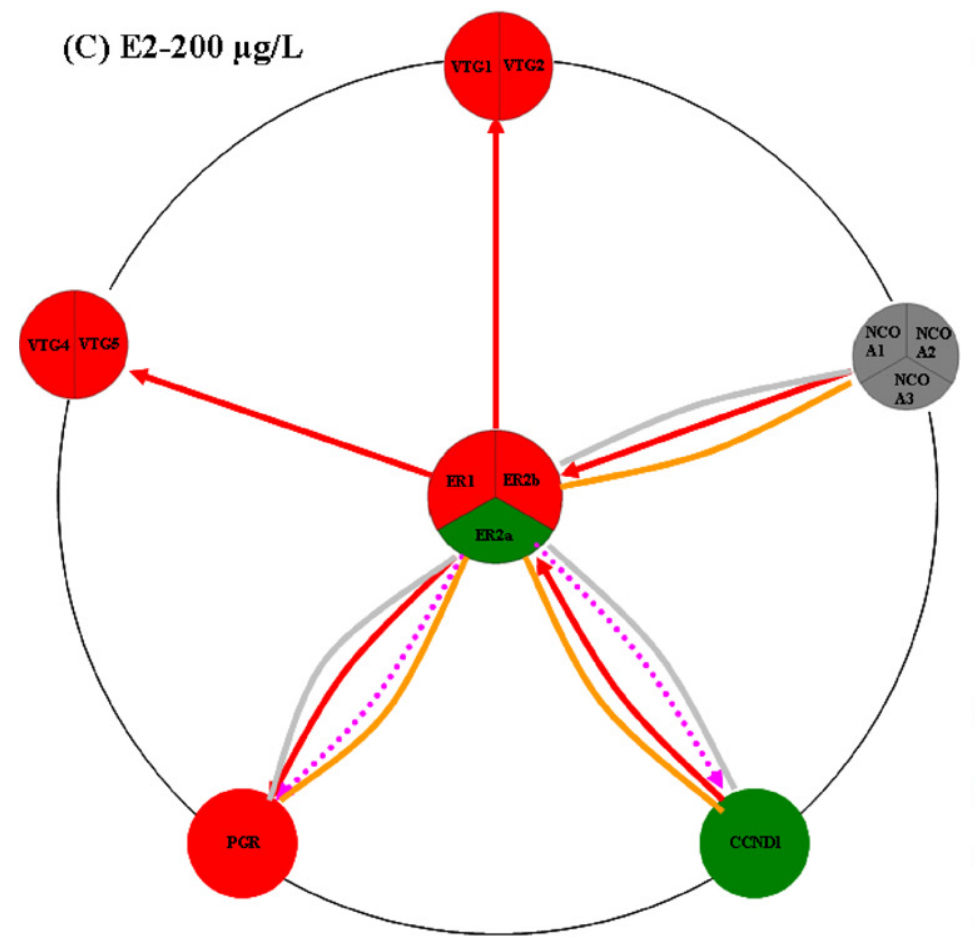

\section{Selectable relationship}
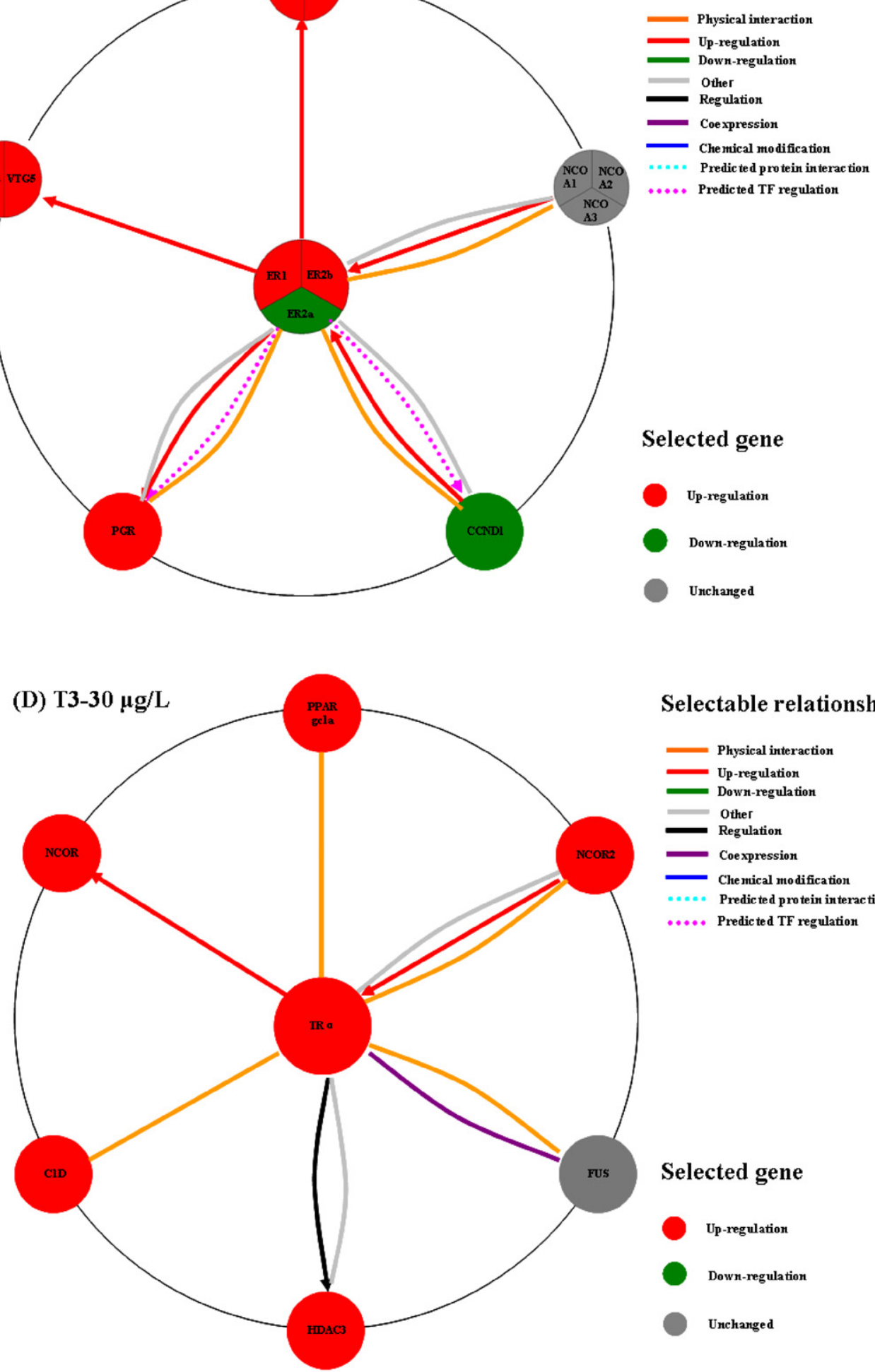

Selectable relationship

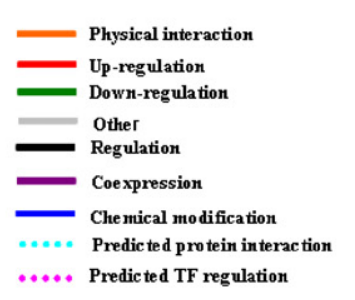

\section{Selected gene}

Up-regulation

Down-regulation

Unchanged

Fig. 3. (Continued)

TR $\alpha$-centered gene network. The following effects were observed at different concentrations of TDCPP: TR $\alpha$ (1.2- and 1.6-fold), PPARgc1a (1.4- and 2.1-fold), NCOR (1.2- and 1.4-fold), C1D (1.2and 1.4-fold), NCOR2 (1.3- and 1.5-fold), HDAC3 (1.2- and 1.4-fold) and FUS (1.5- and 1.8-fold) in 0.2 or $2 \mathrm{mg} / \mathrm{L}$. In the GR-centered gene network, a significant up-regulation in the mRNA expression of GR (1.3- and 1.3-fold), DAP3 (1.3- and 1.8-fold), RelA (1.3- and 1.5-fold), TGFb1 (1.3- and 1.5-fold), and HSP90aa1 (1.2- and 1.9fold) genes was observed upon exposure to 0.2 or $2 \mathrm{mg} / \mathrm{L}$ TDCPP. Exposure to $2 \mathrm{mg}$ TDCPP/L significantly up-regulated expression of mRNAs of MR, 11ßHSD, ADRB2a and UBE2I genes by 1.2-, 1.4-, 1.3and 1.6-fold, respectively. 

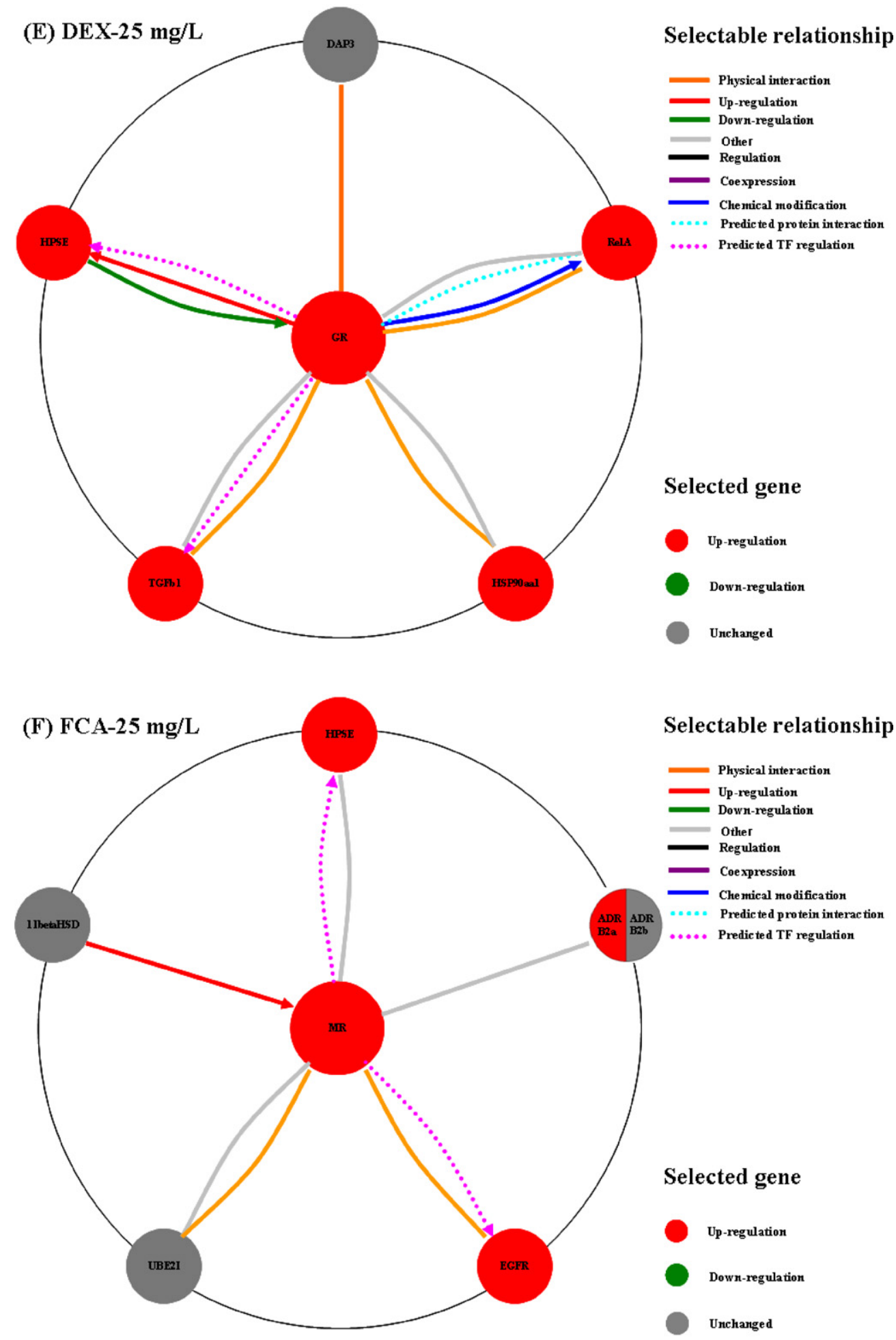

Fig. 3. (Continued)

\subsection{Transcriptional responses to TPP}

TPP caused transcriptional responses mainly in AhRs-, PPAR $\alpha-$ , TR $\alpha-$, GR- and MR-centered gene networks in the present study (Table S2 and Fig. 4). Exposure to $2 \mathrm{mg}$ TPP/L resulted in significant up-regulation of expression of mRNA of CYP1A1, NCOR2 and CYP1B1 genes by 1.7-, 1.5- and 1.4-fold, respectively. In the
PPAR $\alpha$ - and TR $\alpha$-centered gene networks, expressions of mRNA for PPAR $\alpha$, PPARgc1a, LPL, IL6, PPARg, TR $\alpha$, and NCOR2 genes were upregulated by 1.2-, 1.3-, 1.8-, 3.9-, 1.2-, 1.4- and 1.5-fold, respectively, after exposure to $2 \mathrm{mg}$ TPP/L. Exposure to $2 \mathrm{mg}$ TPP/L also upregulated expression of mRNA of RelA, TGFb1, HSP90aa1, 11ßHSD and EGFR genes, while expression of MR and HPSE genes was downregulated. 


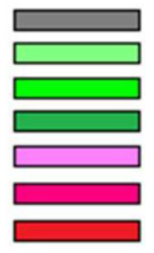

Unchanged

Down-regulation $<1.5$-fold

Down-regulation 1.5-2-fold

Down-regulation $>2$-fold

Up-regulation $<1.5$-fold

Up-regulation 1.5-2-fold

Up-regulation >2-fold

\section{(A) TDCPP}

$0.02 \mathrm{mg} / \mathrm{L} \quad 0.2 \mathrm{mg} / \mathrm{L} \quad 2 \mathrm{mg} / \mathrm{L}$

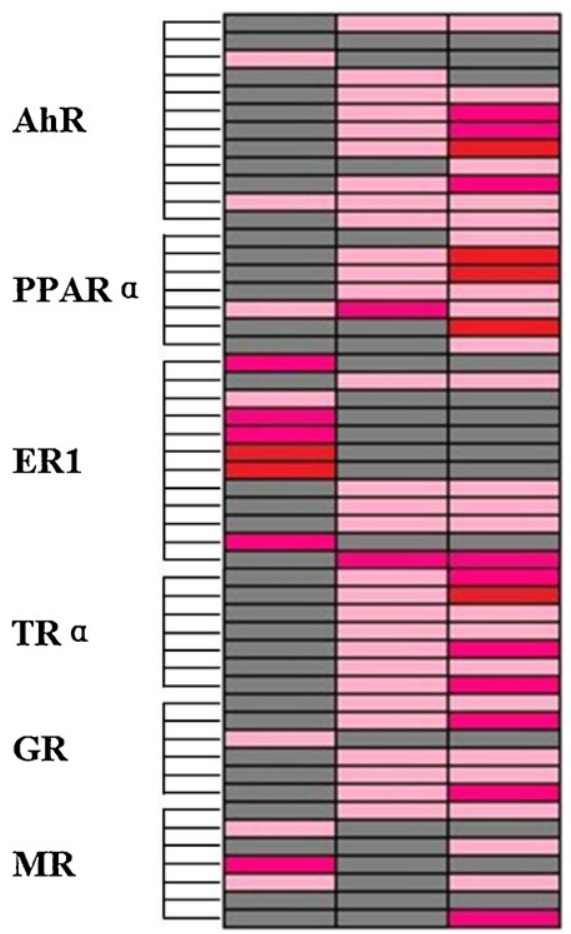

(B) TPP

$0.02 \mathrm{mg} / \mathrm{L} \quad 0.2 \mathrm{mg} / \mathrm{L} \quad 2 \mathrm{mg} / \mathrm{L}$

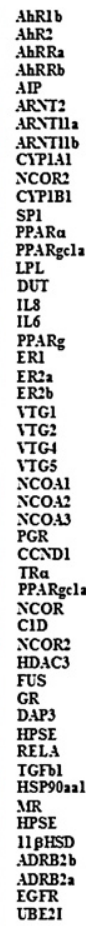

AhR

PPAR a
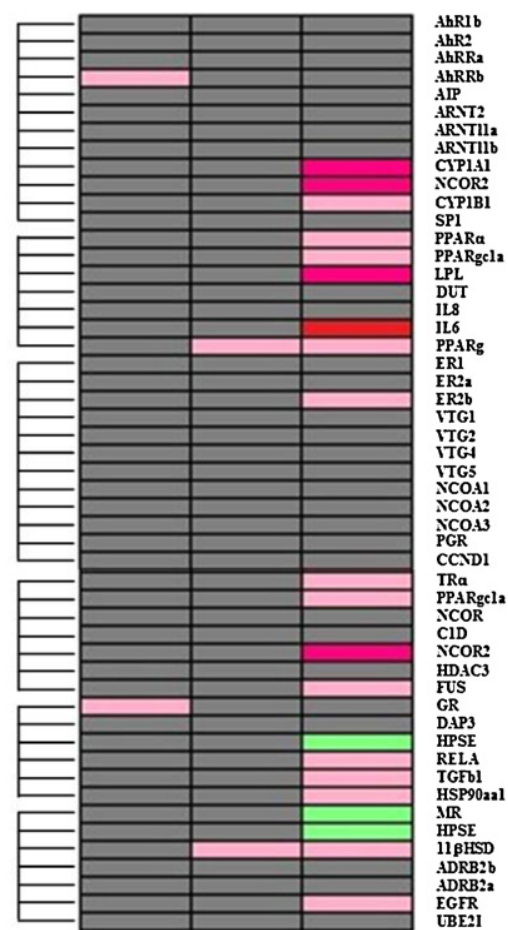

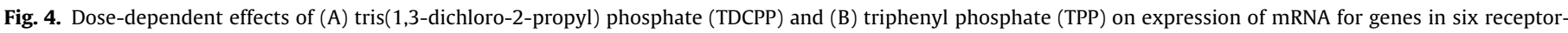
centered gene networks in zebrafish embryos/larvae.

\section{Discussion}

Results of previous studies have suggested that zebrafish embryos/larvae could be used as a model to investigate endocrinedisrupting effects of chemicals (Chen et al., 2012; Jin et al., 2009; Raldúa and Babin, 2009; Yu et al., 2010). In this study, 48 genes involved in six receptor-centered gene networks were collected, and integrated as "associations" and visualized as networks. Furthermore, to evaluate the effects of six positive control chemicals and two organophosphate esters (OP esters: TDCPP and TPP) on mRNA expression along these constructed gene networks, a PCR array was developed for zebrafish embryos/larvae.

Exposure to positive control chemicals B[a]P, PFOS, E2, T3, DEX or FCA altered expression of mRNA in AhRs-, PPAR $\alpha-$-, ERs-, TR $\alpha-$, GR- and MR-centered gene networks, respectively. These results suggested that 5-day old zebrafish larvae could be used to evaluate effects of chemicals on transcription of genes in these receptorcentered gene networks. AhR is a ligand-activated transcription factor that mediates responses to numerous chemicals, such as 2,3,7,8-tetrachlorodibenzo-p-dioxin (TCDD). In zebrafish, there are three AhR genes, AhR1a, AhR1b and AhR2. The AhR1b and AhR2 proteins were capable of high-affinity binding of TCDD and caused associated transcriptional responses, while AhR1a does not appear to be capable of binding TCDD (Andreasen et al., 2002; Karchner and Franks, 2005). Therefore, in the present study, AhR1b and AhR2 were selected and the AhRs-centered gene network was constructed. Exposure to AhR agonists, such as TCDD and B[a]P upregulated expression of AhR, AhRR, AIP, CYP1A1, NCOR2, SP1 and CYP1B1 (Hakkola et al., 1997; Huang et al., 2002; Jin et al., 2012; Ma, 1997; Tsuchiya et al., 2003; Zhang et al., 2006). Those results are consistent with the findings of the study reported upon here. Exposure to B[a]P can significantly up-regulate expression of mRNA for ARNT in mouse hepatoma Hepa1c1c7 cells (Ko et al., 2004). However, no significant alterations in expression of ARNTI1a, ARNT11b or ARNT2 mRNAs were observed in the present study. The reasons for this are not known. There are complicated regulation/interaction relationships between AhRs and ARNTs according to the constructed gene network. Therefore, additional studies might be needed to clarify the relationship between AhRs and ARNTs in zebrafish embryos/larvae after B[a]P exposure in future. Furthermore, exposure to TPP did not alter expression of mRNA of AhR1b or AhR2, but expressions of mRNA of CYP1A1, NCOR2 and CYP1B1 were significantly up-regulated in 2-mg/L exposure group. Therefore, time-course experiments with mRNA and protein might be needed to understand mechanisms. Exposure to TDCPP significantly up-regulated expression of mRNA for AhR1b and all associated genes: AhRRa, AhRRb, AIP, ARNT2, ARNTl1a, ARNTl1b, CYP1A1, NCOR2, CYP1B1 and SP1 in a dose-dependent manner. 
These results suggested that, at least, TDCPP could up-regulate expression of mRNA of AhR1b gene and increase abundances of transcriptions of associated genes.

PPAR $\alpha$ belongs to the nuclear receptor super-family and is involved in lipid homeostasis, inflammation, adipogenesis, reproduction, wound healing and carcinogenesis (Abbott, 2009). In the present study, six genes that were demonstrated to have interaction/regulation relationships with PPAR $\alpha$ were selected. IL6 and IL8 are involved in immune responses and LPL is involved in metabolism of lipids (Moyes et al., 2009). In the present study, exposure to the PPAR $\alpha$ agonist PFOS resulted in significantly greater abundances of mRNA of PPAR $\alpha$, LPL, IL6 and IL8 genes. The results of previous studies have also demonstrated that treatment with PFOS could up-regulate expression of mRNA for IL6 and LPL genes both in vivo and in vitro, which resulted in immunotoxicity (DeWitt et al., 2009; Krøvel et al., 2008; Liao et al., 2012; Wan et al., 2012). DUT catalyses hydrolysis of dUTP to dUMP in the presence of magnesium ions, and is responsible for maintaining balance of pools of free nucleotides in cells (McCarthy et al., 2009). In the present study exposure to PFOS significantly down-regulated expression of mRNA of DUT gene, a result that is opposite to the effect on mRNA expression of PPAR $\alpha$ gene. Therefore, further study might be needed to clarify the relationship between PPAR $\alpha$ and DUT after PFOS exposure. In the present study exposure to TDCPP or TPP significantly up-regulated expression of mRNA of PPAR $\alpha$ and several other genes involved in the PPAR $\alpha$-centered gene network.

ERs are transcriptional factors that can regulate target genes involved in reproduction, development, metabolism and homeostasis in vertebrates (Shibata et al., 1997; McKenna et al., 1999). In zebrafish, there are three ER genes, encoding ER1, ER2a and ER2b. Each protein can bind E2 and transactivate reporter genes in vitro (Menuet et al., 2002). However, specific functions and mechanisms of action of these three ERs remain unknown. In the present study, three ER and nine associated genes, those encoding VTG1, VTG2, VTG4, VTG5, NCOA1, NCOA2, NCOA3, PGR and CCND1, were selected based on the information from Gene Network Central and previous published results of studies with fishes and were integrated as "associations". Exposure to E2 significantly up-regulated mRNA expressions of ER1 (ER $\alpha)$, ER2b (ER $\beta 2)$, VTG1, VTG2, VTG4, VTG5 and PGR, and down-regulated mRNA expressions of ER2a (ER $\beta 1)$ and CCND1 in 5-day zebrafish larvae. mRNA expressions of NCOAs (NCOA1, NCOA2 and NCOA3) were not changed. These results suggest that different ERs might have different functions. The results of a previous study demonstrated that E2 exposure up-regulated $E R \alpha$ expression and down-regulated ER $\beta 1$ expression, while expression of ER $\beta 2$ remained unchanged in liver of zebrafish (Menuet et al., 2004). In the present study when embryos were exposed to TPP, mRNA expression of only ER2b was slightly up-regulated, while mRNA expression of other genes was not significantly altered. However, exposure to TDCPP caused significant up-regulation of mRNA expression of all the genes selected, a result that suggests that TDCPP might have estrogenic activity. The results of a previous study have also demonstrated that TDCPP can increase the concentration of E2 in blood plasma and up-regulate expression of VTG in zebrafish (C. Liu et al., 2012; X. Liu et al., 2012). Our results suggest, according to integrated "associations" between these genes in this study, that up-regulation of expression of VTGs and PGR might have resulted from up-regulation of ER1 and ER2b, and up-regulation of ER2a might be the result from up-regulation of expression of NCOAs. When exposed to E2 down-regulation of mRNA expression of ER2a gene was accompanied by down-regulation of mRNA expression of CCND1 gene, while mRNA expression of NCOA genes was not affected. This result suggests that down-regulation of expression of CCND1 might be responsible for the observed down-regulation of expression of ER2a after exposure to E2. Collectedly, the results demonstrated that TDCPP could up-regulate mRNA expressions of ER1, ER2b and other associated genes, such as VTGs, and thus might have estrogenic activity.

Thyroid hormones, thyroxine (T4) and triiodothyronine (T3) are produced by the thyroid gland, and their roles in development and metabolism have been well established in vertebrates (Power et al., 2001). The two hormones (T4 and T3) exert their major effects by binding to their receptors (TRs), such as TR $\alpha$ in zebrafish (Power et al., 2001). In this study, six genes were selected and integrated as "associations". Exposure to T3 up-regulated mRNA expression of all the genes selected except for FUS, which suggests that the TR $\alpha$ associated pathway was responsible for exposure to TR agonists in 5-day zebrafish larvae. Treatment with TPP or TDCPP caused transcriptional responses in the TR $\alpha$-associated pathway, where TDCPP had greater potency. The results of an epidemiology study suggested that TDCPP and TPP might had thyroid system-disrupting activity, where TDCPP and TPP concentrations in dust were correlated with the concentrations of free T4 in human plasma (Meeker and Stapleton, 2010). The results of the correlation analysis suggested that TDCPP and TPP could modulate functions of the thyroid system by interacting with TR $\alpha$. Steroid hormones, including glucocorticoids and mineralocorticoids, are essential for regulation of diverse physiological functions, such as glucose metabolism, mineral balance, and behavior (Greenwood et al., 2003). Glucocorticoids and mineralocorticoids exert their major effects by binding to their receptors (GR and MR, respectively), thus resulting in alterations in down-stream transcription (Greenwood et al., 2003). In the present study, exposure to GR or MR agonist significantly upregulated mRNA expression of several genes involved in GR- or MR-centered gene networks, which suggests that it is feasible to use 5-day old zebrafish larvae to evaluate effects of chemical on GRand MR-associated mRNA expression. Treatment with TDCPP or TPP significantly up-regulated expression of GR and MR and several other genes involved in the two gene networks.

In summary, the results of this study confirmed that 5-day old zebrafish larvae could be used to evaluate the effects of chemicals on mRNA expression in AhR-, PPAR $\alpha-$, ER-, TR $\alpha-$, GR- and MR-centered gene networks. Exposure to TDCPP altered profiles or relative abundances of transcripts of all the receptor-centered gene networks studied. TPP was less potent compared with TDCPP, and the PPAR $\alpha$ - and TR $\alpha$-centered gene networks were the primary targets for TPP. Furthermore, TPP could be easily metabolized by zebrafish larvae, which might be primary reason for weaker potency in altering expression of mRNAs involved in receptor-centered gene networks compared with TDCPP. In addition, concentrations of TDCPP or TPP that we determined to be effective in expression of mRNAs involved in six receptor-centered gene networks in this study were several orders of magnitude greater than those reported in the water environment (Andresen et al., 2004; van der Veen and de Boer, 2012). Therefore, direct effects of TDCPP or TPP on expression of mRNA involved in these receptor-centered networks might not be expected at their current levels of occurrence.

\section{Acknowledgements}

This work was supported by grants from the National Natural Science Foundation of China (21207063) and the Natural Science Foundation of Jiangsu Province, China (BK2011032, BK2010384). Prof. Giesy was supported by the Canada Research Chair program, an at large Chair Professorship at the Department of Biology and Chemistry and State Key Laboratory in Marine Pollution, City University of Hong Kong, and the Einstein Professor Program of the Chinese Academy of Sciences. 


\section{Appendix A. Supplementary data}

Supplementary data associated with this article can be found, in the online version, at http://dx.doi.org/10.1016/ j.aquatox.2012.12.010.

\section{References}

Abbott, B.D., 2009. Review of the expression of peroxisome proliferator-activated receptors alpha (PPAR $\alpha)$, beta (PPAR $\beta)$, and gamma (PPAR $\gamma$ ) in rodent and human development. Reproductive Toxicology 27, 246-257.

Amsterdam, A., Nissen, R.M., Sun, Z., Swindell, E.C., Farrington, S., Hopkins, N., 2004. Identification of 315 genes essential for early zebrafish development. Proceedings of the National Academy of Sciences of the United States of America 101, 12792-12797.

Andreasen, E.A., Spitsbergen, J.M., Tanguay, R.L., Stegeman, J.J., Heideman, W., Peterson, R.E., 2002. Tissue-specific expression of AHR2, ARNT2, and CYP1A in zebrafish embryos and larvae: effects of developmental stage and 2,3,7,8tetrachlorodibenzo-p-dioxin exposure. Toxicological Sciences 68, 403-419.

Andresen, J.A., Grundmann, A., Bester, K., 2004. Organophosphorus flame retardants and plasticisers in surface waters. Science of the Total Environment 332, 155-166.

Ankley, G.T., Bennett, R.S., Erickson, R.J., Hoff, D.J., Hornung, M.W., Johnson, R.D., Mount, D.R., Nichols, J.W., Russom, C.L., Schmieder, P.K., Serrrano, J.A., Tietge, J.E., Villeneuve, D.L., 2010. Adverse outcome pathways: a conceptual framework to support ecotoxicology research and risk assessment. Environmental Toxicology and Chemistry 29, 730-741.

Bacaloni, A., Cavaliere, C., Foglia, P., Nazzari, M., Samperi, R., Lagana, A., 2007. Liquid chromatography/tandem mass spectrometry determination of organophosphorus flame retardants and plasticizers in drinking and surface waters. Rapid Communications in Mass Spectrometry 21, 1123-1130

Cao, S., Zeng, X., Song, H., Li, H., Yu, Z., Sheng, G., Fu, J., 2012. Levels and distributions of organophosphate flame retardants and plasticizers in sediment from Taihu Lake, China. Environmental Toxicology Chemistry 31, 1478-1484.

Chen, D., Letcher, R.J., Chu, S., 2011. Determination of non-halogenated, chlorinated and brominated organophosphate flame retardants in herring gull eggs based on liquid chromatography-tandem quadrupole mass spectrometry. Journal of Chromatography A 1220, 169-174.

Chen, Q. Yu, L., Yang, L., Zhou, B., 2012. Bioconcentration and metabolism of decarbomodiphenyl ether (BDE-209) result in thyroid endocrine disruption in zebrafish larvae. Aquatic Toxicology 110, 141-148.

Crump, D., Chiu, S., Kennedy, S.W., 2012. Effects of tris(1,3-dichloro-2-propyl) phosphate and tris(1-chloropropyl) phosphate on cytotoxicity and mRNA expression in primary cultures of avian hepatocytes and neuronal cells. Toxicological Sciences $126,140-148$.

DeWitt, J.C., Shnyra, A., Badr, M.Z., Loveless, S.E., Hoban, D., Frame, S.R., Cunard, R. Anderson, S.E., Meade, B.J., Peden-Adams, M.M., Luebke, R.W., Luster, M.I., 2009. Immunotoxicity of perfluorooctanoic acid and perfluorooctane sulfonate and the role of peroxisome proliferator-activated receptor alpha. Critical Reviews in Toxicology 39, 76-94.

Dishaw, L.V., Powers, C.M., Ryde, I.T., Roberts, S.C., Seidler, F.J., Slotkin, T.A., Stapleton, H.M., 2011. Is the pentaBDE replacement, tris(1,3-dichloro-2-propyl) phosphate (TDCPP), a developmental neurotoxicant? Studies in PC12 cells. Toxicology and Applied Pharmacology 256, 281-289.

Duarte-Guterman, P., Langlois, V.S., Pauli, B.D., Trudear, V.L., 2010. Expression and T3 regulation of thyroid hormone- and sex steroid-related genes during silurana (Xenopus) tropicalis early development. General and Comparative Endocrinology $166,428-435$.

Greenwood, A.K., Butler, P.C., White, R.B., Demarco, U., Pearce, D., Fernald, A.D., 2003. Multiple corticosteroid receptors in a teleost fish: distinct sequences, expression patterns, and transcriptional activities. Endocrinology 144, 4226-4236.

Hakkola, J., Pasanen, M., Pelkonen, O., Hukkanen, J., Evisalmi, S., Anttila, S., Rane, A., Mäntylä, M., Purkunen, R., Saarikoski, S., Tooming, M., Raunio, H., 1997. Expression of CYP1B1 in human adult and fetal tissues and differential inducibility of CYP1B1 and CYP1A1 by Ah receptor ligands in human placenta and cultured cells. Carcinogenesis 18, 391-397.

Hartmann, P.C., Burgi, D., Giger, W., 2004. Organophosphate flame retardants and plasticizers in indoor air. Chemosphere 57, 781-787.

Huang, P., Ceccatelli, S., Håkansson, H., Grandison, L., Rannug, A., 2002. Constitutive and TCDD-induced expression of Ah receptor-responsive genes in the pituitary. Neurotoxicology 23, 783-793.

Jin, K., Park, C.M., Lee, Y., 2012. Identification of differentially expressed genes by 2,3,7,8-tetrachlorodibenzo-p-dioxin in human bronchial epithelial cells. Human and Experimental Toxicology 31, 107-112.

Jin, Y., Chen, R., Sun, L., Qian, H., Liu, W., Fu, Z., 2009. Induction of estrogenresponsive gene transcription in the embryo, larval, juvenile and adult life stages of zebrafish as biomarkers of short-term exposure to endocrine disrupting chemicals. Comparative Biochemistry and Physiology 150C, 414-420.

Karchner, S.I., Franks, D.G., hahn, M.E., 2005. AHR1B, a new functional aryl hydrocarbon receptor in zebrafish: tandem arrangement of ahr1b and ahr2 genes. Biochemistry Journal 15, 153-161.

Kazeto, Y., Place, A.R., Trant, J.M., 2004. Effects of endocrine disrupting chemicals on the expression of CYP19 genes in zebrafish (Danio rerio) juveniles. Aquatic Toxicology 69, 25-34.
Ko, C., Kim, S., Park, C., Kim, B., Shin, C., Choi, S., Chung, S., Noh, J., Jeun, J., Kim, N., Park, R., 2004. Benzo(a)pyrene-induced apoptotic death of mouse hepatoma Hepa1c1c7 cells via activation of intrinsic caspase cascade and mitochondrial dysfunction. Toxicology 199, 35-46.

Krøvel, A.V., Søfteland, L., Torstensen, B., Olsvik, P.A., 2008. Transcriptional effects of PFOS in isolated hepatocytes from Atlantic salmon Salmo salar L. Comparative Biochemistry and Physiology 148C, 14-22.

Liao, Y., Wang, J., Huang, Q., Fang, C., Kiyama, R., Shen, H., Dong, S., 2012. Evaluation of cellular response to perfluorooctane sulfonate in human umbilical vein endothelial cells. Toxicology In Vitro 26, 421-428.

Liu, C., Yu, L., Deng, J., Lam, P.K.S., Wu, R.S.S., Zhou, B., 2009. Waterborne exposure to fluorotelomer alcohol 6:2 FTOH alters plasma sex hormone and gene transcription in the hypothalamic-pituitary-gonadal (HPG) axis of zebrafish. Aquatic Toxicology 93, 131-137.

Liu, C., Yan, W., Zhou, B., Guo, Y., Liu, H., Yu, H., Giesy, J.P., Wang, J., Li, G., Zhang, X., 2012. Characterization of a bystander effect induced by the endocrine-disrupting chemical 6-propyl-2-thiouracil in zebrafish embryos. Aquatic Toxicology 118, 108-115.

Liu, X., Ji, K., Choi, K., 2012. Endocrine disruption potentials of organophosphate flame retardants and related mechanisms in H295R and MVLN cell lines and in zebrafish. Aquatic Toxicology 114, 173-181.

Ma Jr., Q.J.P.W., 1997. A novel cytoplasmic protein that interacts with the Ah receptor, contains tetratricopeptide repeat motifs, and augments the transcriptional response to 2,3,7,8-tetrachlorodibenzo-p-dioxin. Journal of Biological Chemistry 272, 8878-8884.

Mandal, P.K., 2005. Dioxin: a review of its environmental effects and its aryl hydrocarbon receptor biology. Journal of Comparative Physiology 175B, 221-230.

Marklund, A., Andersson, B., Haglund, P., 2005. Organophosphorus flame retardants and plasticizers in air from various indoor environment. Journal of Environmental Monitoring 7, 814-819.

McCarthy, O., Musso-Buendia, A., Kaiser, M., Brun, R., Ruiz-Perez, L.M., Johansson, N.G., pacanowska, D.G., Gilbert, I.H., 2009. Design, synthesis and evaluation of novel uracil acetamide derivatives as potential inhibitors of Plasmodium falciparum dUTP nucleotidohydrolase. European Journal of Medical Chemistry 44 678-688.

McGee, S.P., Cooper, E.M., Stapleton, H.M., Volz, D.C., 2012. Early zebrafish embryogenesis is susceptible to developmental TDCPP exposure. Environmental Health Perspectives 120, 1585-1591.

McKenna, N.J., Lanz, R.B., O’Malley, B.W., 1999. Nuclear receptor co-regulators: cellular and molecular biology. Endocrine Reviews 20, 321-344.

McKenna, N.J., O’Malley, B.W., 2002. Combinatorial control of gene expression by nuclear receptors and coregulators. Cell 108, 465-474

Meeker, J.D., Stapleton, H.M., 2010. House dust concentrations of organophosphate flame retardants in relation to hormone levels and semen quality parameters. Environmental Health Perspectives 118, 318-323.

Menuet, A., Pellegrini, E., Anglade, I., Blaise, O., Laudet, V., Kah, O., Pakdel, F., 2002 Molecular characterization of three estrogen receptor forms in zebrafish: binding characteristics, transactivation properties, and tissue distributions. Biology of Reproduction 66, 1881-1892.

Menuet, A., Page, Y.L., Torres, O., Kern, L., Kah, O., Pakde, F., 2004. Analysis of the estrogen receptor (ER) reveals distinct effects of ERalpha, ERbeta1 and ERbeta2. Journal of Molecular Endocrinology 32, 975-986.

Mortensen, A.S., Arukwe, A., 2007. Effects of $17 \alpha$-ethynylestradiol on hormona responses and xenobiotic biotransformation system of atlantic salmon (Salmo salar). Aquatic Toxicology 85, 113-123.

Moyes, K.M., Drackley, J.K., Morin, D.E., Bionaz, M., Rodriguez-Zas, S.L., Everts, R.E., Lewin, H.A., Loor, J.J., 2009. Gene network and pathway analysis of bovine mammary tissue challenged with Streptococcus uberis reveals induction of cell proliferation and inhibition of PPAR $\gamma$ signaling as potential mechanism for the negative relationships between immune response and lipid metabolism. BMC Genomics 10, 542.

Pellegrini, E., Menuet, A., Lethimonier, C., Adrio, F., Gueguen, M.M., Tascon, C., Anglade, I., Pakdel, F., Kah, O., 2005. Relationships between aromatase and estrogen receptors in the brain of teleost fish. General and Comparative Endocrinology 142, 60-66.

Power, D.M., Llewellyn, L., Faustino, M., Nowell, M.A., Bjornsson, B.T., Einarsdottir, I.E., Canario, A.V.M., Sweeney, G.E., 2001. Thyroid hormones in growth and development of fish. Comparative Biochemistry and Physiology 130C, 447-459.

Raldúa, D., Babin, P.J., 2009. Simple, rapid zebrafish larva bioassay for assessing the potential of chemical pollutants and drugs to disrupt thyroid gland function. Environmental Science and Technology 43, 6844-6850.

Reemtsma, J., Quintana, J., Rodil, R., García-López, M., Rodríguez, I., 2008 Organophosphorus flame retardants and plasticizers in water and air. I. Occurrence and fate. Trends in Analytical Chemistry 27, 727-737.

Shi, X., Liu, C., Wu, G., Zhou, B., 2009. Waterborne exposure to PFOS causes disruption of the hypothalamic-pituitary-thyroid axis in zebrafish larvae. Chemosphere 77 . 1010-1018.

Shibata, H., Spencer, T.E., Onate, S.A., Jenster, G., Tsai, S.Y., Tsai, M., O’Malley B.W., 1997. Role of co-activators and co-repressors in the mechanism of steroid/thyroid receptor action. Recent Progress in Hormone Research 52, 141-149.

Stackelberg, P.E., Furlong, E.T., Meyer, M.T., Zaugg, S.D., Henderson, A.K., Reissman D.B., 2004. Persistence of pharmaceutical compounds and other organic wastewater contaminants in a conventional drinking-water-treatment plant. Science of the Total Environment 329, 99-113. 
Sundkvist, A.M., Olofsson, U., Haglund, P., 2010. Organophosphorus flame retardants and plasticizers in marine and fresh water biota and in human milk. Journal of Environmental Monitoring 12, 943-951.

Tseng, H., Hseu, T., Buhler, D.R., Wang, W., Hu, C., 2005. Constitutive and xenobioticsinduced expression of a novel CYP3A gene from zebrafish larva. Toxicology and Applied Pharmacology 205, 247-258.

Tsuchiya, Y., Nakajima, M., Yokoi, T., 2003. Critical enhancer region to which AhR/ARNT and Sp1 bind in the human CYP1B1 gene. Journal of Biochemistry 133, 583-592.

van der Veen, I., de Boer, J., 2012. Phosphorus flame retardants: properties, production, environmental occurrence, toxicity and analysis. Chemosphere 88 , 1119-1153.

Wan, H.T., Zhao, Y.G., Wei, X., Hui, K.Y., Giesy, J.P., Wong, C.K.C., 2012. PFOS-induced hepatic steatosis, the mechanistic actions on $\beta$-oxidation and lipid transport. Biochimica et Biophysica Acta 1820, 1092-1101.

Wang, J., Shi, X., Du, Y., Zhou, B., 2011. Effects of xenoestrogens on the expression of vitellogenin (vtg) and cytochrome P450 aromatase (cyp19a and b) genes. Journal of Environmental Science and Health 40A, 960-967.
Wang, X., Liu, J., Yin, Y., 2011. Development of an ultra-high-performance liquid chromatography-tandem mass spectrometry method for high throughput determination of organophosphorus flame retardants in environmental water. Journal of Chromatography A 1218, 6705-6711.

Yu, L., Deng, J., Shi, X., Liu, C., Yu, K., Zhou, B., 2010. Exposure to DE-71 alters thyroid hormone levels and gene transcription in the hypothalamic-pituitary-thyroid axis of zebrafish larvae. Aquatic Toxicology 97, 226-233.

Zhang, X., Hecker, M., Jones, P.D., Newsted, J., Au, D., Kong, R., Wu, R.S.S., Giesy, J.P., 2008. Responses of the medaka HPG axis PCR array and reproduction to prochloraz and ketoconazole. Environmental Science and Technology 42, 6762-6769.

Zhang, Z., Pelletier, R.D., Wong, Y.N., Sugawara, M., Zhao, N., Littlefield, B.A., 2006. Preferential inducibility of CYP1A1 and CYP1A2 by TCDD: differential regulation in primary human hepatocytes versus transformed human cells. Biochemical and Biophysical Research Communications 341, 399-407. 